\title{
Introduction to the Special Issue on School Safety: Increasing Understanding/Decreasing Misunderstandings in the Realm of School Safety
}

\author{
David C. May ${ }^{1}$
}

Received: 19 January 2018 / Accepted: 19 January 2018 /

Published online: 2 February 2018

(C) Southern Criminal Justice Association 2018

A review of any library catalog (or any popular bookseller website, for that matter) will reveal a number of book titles in the area of school violence. Titles such as Violence among Students and School Staff (Brooks, 2017), Violence in America's Schools (Thomas, 2006), Suicide, Self-Injury, and Violence in Schools (Juhnke, Granello, \& Granello, 2010), and Violence in Schools (Sexton-Radek, 2005) reflect the strategy of publishers and/or authors to draw attention to the topic from a provocative, eyecatching perspective by focusing on violence. Additionally, journals in the field of education have dedicated entire issues to preventing school violence from their disciplinary lens (Mayer, 2001; Mayer \& Cornell, 2010) and an entire journal publishes four issues each year on this topic (Journal of School Violence). Although recent works (Kupchik, 2016; May, 2014; Timm, 2015) have reversed this trend and reflect the fact that school safety is much larger than prevention of what is traditionally considered as school violence, most Americans still think of school safety as "preventing school violence."

Thus, any article or discussion of school safety likely should begin with a definition of how that term is used in the current context (May, 2014). I want to introduce this special edition to the journal by providing an operational definition of school safety from the United States Department of Education Office of Safe and Drug Free Schools that will serve as an umbrella under which the articles in this journal are covered. For the purpose of this issue, school safety is defined as "the safety of school settings, such as the incidence of harassment, bullying, violence, and substance use, as supported by relevant research and an assessment of validity" (Office of Safe and Drug Free Schools, Department of Education, 2011, p. 19983).

As I have argued elsewhere (May, 2014), the first part of that definition is familiar to most readers and would better be described as "school unsafety," capturing the concern

David C. May

dmay@soc.msstate.edu

1 Mississippi State University, Mississippi State, MS, USA 
of the typical person discussing school safety. The typical person can name at least one relatively recent school shooting (Sandy Hook, in Newton, Connecticut, would be the incident that came to most people's mind at the time of this writing, although there have been many school shootings since December 2012 when that one occurred). Nevertheless, most people cannot identify even one situation where a serious incident was prevented because a student told a trusted adult in the school setting about one of their fellow students' intent to do harm to themselves or others even though these situations happen countless times each year.

To gain a better understanding of school safety requires close attention to the second part of that definition "... as supported by relevant research and an assessment of validity" (Office of Safe and Drug Free Schools, Department of Education, 2011, p. 19983). In this issue, the authors have contributed mightily to this effort. Without exception, the articles in this issue are data-driven, empirically sound, and grounded in the relevant literature. When we issued the call for papers for this special issue, we purposefully made it general enough where a variety of topics could fit under the school safety umbrella. Nevertheless, the submissions we received revolved largely around topics that are daily challenges for K-12 school administrators: students' perceptions of safety in school, bullying, school security measures, and school police. Despite this fact, while the articles included in this volume may be topics that are addressed in other venues, it is difficult to find another publication where these topics are addressed in one venue, with sound empirical analyses followed by thoughtful policy recommendations based on those analyses. Thus, I believe that readers interested in the topic of school safety will find this entire issue an essential "tool in their toolkit" as they seek to understand the topic of school safety.

\section{School Safety Statistics}

May (2014) and Cornell (2006) suggest that any discussion of school violence and/or school safety must also consider youth crime and violence outside of schools. They argue that, despite the rhetoric that most of the attention to school violence began with the mass shooting at Columbine, the focus on school violence actually began earlier than that, with Dilulio's article that appeared in The Weekly Standard entitled "The Coming of the Superpredator." DiIulio argues that an emerging group of violent young males engaged in serious, repeated violence (youths he labeled as "super-predators") would increase dramatically by the end of the twentieth century and create a youth crime explosion by 2010. May (2014) argues that the widespread attention given this article over the next 5 years (despite the fact that his predictions never were realized), coupled with school shootings at Columbine and other schools, brought the issue of youth crime, and particularly youth crime in schools, to everyone's attention.

May (2014) argues that the media have played a large role in the creation of an environment where the general public feels schools are unsafe venues and children's lives are at risk daily when they attend public schools throughout the country. Fortunately, in 2018, this myth is much easier to dismiss than at any point in our history. The most comprehensive report about school safety is free and publicly available. Thus, rather than bore the reader with a plethora of tables about the incidence, prevalence, and types of crime that occur on school grounds, I will simply refer you to that report 
entitled Indicators of School Crime and Safety, 2016, available for free download from the National Center for Education Statistics and the Bureau of Justice Statistics (National Center for Education Statistics, 2017). Citations from this report or its predecessors are used by a number of the authors in this special edition. I would encourage all readers of this volume to read that report, as it is the most comprehensive descriptive analysis of school safety in public schools that is available, and provides the most realistic estimate of school crime available.

While the topics covered in this issue certainly do not cover all aspects of school safety, I believe that the depth provided around each topic covered here makes an important contribution. In the first article in this issue, entitled "Adding Security, but Subtracting Safety? Exploring Schools' Use of Multiple Visible Security Measures," Emily Tanner-Smith and her colleagues analyze nationally representative, quasiexperimental data from the School Survey on Crime and Safety to determine whether implementation of visible security measures impact administrator reports of drug problems, fighting, property crime, and firearms at school. Their findings may be somewhat surprising to school administrators and their policy implications from those findings provide sensible suggestions that would benefit any school administrator to consider in their overall school safety planning process.

In the second article in this issue, "Students' Feeling of Safety in School: Does Frequency of Victimization Matter?," Yaacov Yablon and Lynn Addington examine the effect of repeated victimization experiences on feelings of safety using data from a large sample of Israeli Jewish and Arab students. While, intuitively, victimization at school should make students' more likely to be fearful of further victimization, the research findings in this area suggest that may not always be the case. Yablon and Addington's research suggest that the relationship between victimization and perceptions of safety in school may be more complicated the previous research suggests, and provide a number of explanations for why serial victimization may have a different impact on perceptions of safety in school than a single victimization.

The next article in this issue, "Reaching Out vs. Lashing Out: Examining Gender Differences in Experiences with and Response to Bullying in High Schools" by Megan Stubbs-Richardson and her colleagues, examines a topic that has previously been examined by a large number of authors across a variety of disciplines: bullying. Nevertheless, Stubbs-Richardson and her colleagues provide an innovative approach to the topic of bullying by comparing victimization and perpetration rates across four subtypes of bullying: physical, verbal, relational, and cyber. Their findings suggest that bullying victimization, and responses to bullying victimization, are gendered. Males are more likely to be involved in both verbal and physical bullying (as both victims and perpetrators) that girls, but that is not the case for all types of bullying. They also determined that responses to bullying vary by gender, and provide interesting implications for bullying prevention based on their findings.

The fourth article in this issue also examines bullying victimization. In her article entitled "How Do Traditional Bullying and Cyberbullying Victimization Affect Fear and Coping among Students? An Application of General Strain Theory" Shelley Keith uses data from the National Crime Victimization School Crime Supplement to examine bullying victimization through the lens of general strain theory and then examines how bullying victimization impacts fear of crime at school, avoidance behaviors, and weapon carrying at school. Her findings may be somewhat surprising and continue 
the theme developed in earlier articles that the impact of victimization at school is multifaceted, and sometimes counterintuitive.

In the next article entitled "Examining the Long-Term Consequences of Bullying on Adult Substance Use," Susan Quinn and Megan Stewart use data from the 1997 National Longitudinal Survey of Youth to examine the association between schoolaged bullying (under the age of 19) and adult alcohol, cigarette, and drug use, also through the lens of general strain theory. While a large body of research demonstrates the negative consequences that bullying has for victims during adolescence, Quinn and Stewart's study is one of a small number to examine how bullying affects an individual into adulthood. Their findings suggest that, after controlling for other predictors of substance use in adulthood, bullying victimization does not have a strong impact on adult substance use. Thus, if there is good news about bullying, it is that its negative consequences may diminish as victims move into adulthood.

The next article in this issue, "Students' Feelings of Safety, Exposure to Violence and Victimization, and Authoritative School Climate," shifts the focus of victimization at school from bullying to the relationship between school climate and feelings of safety among students at school. In that article, Benjamin Fisher and his colleagues use data from two nationally representative datasets to better understand the relationship between authoritative school climate and feelings of safety, exposure to violence, and victimization among public school students. Their findings suggest that a more authoritative school climate is associated with increased feelings of safety at school. Fisher and colleagues argue that strengthening students' relationships with adults, coupled with increasing the fairness and consistency of rules in the school, may reduce exposure to violence and victimization and help students feel safer at school.

The final article in this issue, "School Resource Officers and the School to Prison Pipeline: Discovering Trends of Expulsions in Public Schools" investigates the impact of school police on the number of expulsions in a school and the total number of incidents reported by law enforcement when police officers are stationed in schools. Using data from over 3000 public school principals from throughout the United States, Christina Pigott and her colleagues uncover a finding that counters much of the rhetoric around the school to prison pipeline. At least from the principals' reports, the analyses by Pigott and her associates suggest the relationship between the presence of school police on campus, and the type of personnel that are being used in the policing role, is much more complicated than the simple argument (supported by so many in the schoolto-prison pipeline literature) that the presence of police in school increases the number of students removed from the school and involved in the criminal justice system for minor offenses.

As readers peruse the articles in this work, they may be left with the perception that the authors of these articles typically conclude their works with more questions than answers. I would concur with that assessment. The articles presented here combine to develop one overarching theme. Reducing violence, and increasing safety, in school settings is difficult, and often complicated, requiring a multifaceted approach to school safety that may work one on campus but not another. I encourage readers to keep that finding in mind as they work to find solutions to school safety problems in the United States and throughout the world. Oscar Wilde is attributed with the following famous quote- "The truth is rarely pure and never simple." I would suggest that, if we accept that statement as factual, its corollary in the realm of school safety is also true- "Simple 
solutions are rarely effective, and effective solutions are rarely simple." The work in this issue bears that out.

I would be remiss if I did not close by thanking all the authors and reviewers that contributed to this issue. My friend and colleague Makeela Wells, the managing editor for this issue, was essential in the completion of this issue. She secured reviewers, followed up with them, and, in general, brought this issue from an idea to a real volume readers can hold in our hands. When we searched for reviewers, we used the library search engines to identify over 50 researchers that had published in the area of school safety over the last 3 years. With very few exceptions, these authors (most of whom I don't know personally), kindly agreed to review the articles submitted for this journal; their help was invaluable, their reviews were thorough and timely, and even those articles that were rejected benefitted from their careful review. Furthermore, without the authors that contributed to this work, and their willingness to incorporate revisions from the aforementioned reviewers, this issue would not have ever happened. Finally, I cannot say enough about the responsiveness and patience of Wesley Jennings, his editorial team, and Springer Publishing. Any delay in publication of this issue was my own fault, never that of Wesley or Springer. Thanks to all of those mentioned for their help.

\section{References}

Brooks, S. M. (2017). Violence among students and school staff: Understanding and preventing the causes of school violence. North Charleston: CreateSpace Independent Publishing Platform.

Juhnke, G. A., Granello, D. H., \& Granello, P. F. (2010). Suicide, self-injury, and violence in the schools: Assessment, prevention, and intervention strategies. Hoboken: Wiley.

Kupchik, A. (2016). The real school safety problem: The long-term consequences of harsh school punishment. Oakland: University of California Press.

May, D. C. (2014). School safety in the United States: A reasoned look at the rhetoric. Durham: Carolina Academic Press.

Mayer, G. R. (2001). Introduction to the special issue on school violence. Education and Treatment of Children, 24(4), 411-413.

Mayer, M. J., \& Cornell, D. G. (2010). New perspectives on school safety and violence prevention: Guest editor's preface. Educational Researcher, 39(1), 5-6.

Office of Safe and Drug Free Schools, Department of Education. (2011). Funding priorities, requirements, and definitions. Federal Register, 76(69), 19983. Available electronically at https://www.gpo. gov/fdsys/pkg/FR-2011-04-11/pdf/2011-8461.pdf.

National Center for Education Statistics. (2017). Indicators of school crime and safety: 2016. Washington D.C.: Author. Available electronically at https://nces.ed.gov/pubs2017/2017064.pdf

Sexton-Radek, K. (2005). Violence in schools: Issues, consequences, and expressions. Westport: Praeger.

Thomas, R. M. (2006). Violence in America's schools: Understanding, prevention, and response. Westport: Praeger.

Timm, P. (2015). School security: How to build and strengthen a school safety program. Waltham: Elsevier.

David C. May is a Professor in the Department of Sociology at Mississippi State University. David has authored or coauthored six books and over 80 scholarly articles and book chapters around his research interests of fear of crime, school safety, cyber violence, corrections, military sociology, and human robot interaction. Dr. May is currently a co-PI on two funded projects designed to reduce the harmful effects of bullying (one funded by the National Institute of Justice and one by the National Science Foundation) and is also working on a multi-state interview project to better understand the school-to-prison pipeline. 